\title{
Sex, power and drugs: the murky world of malaria parasite mitochondria
}

\author{
Giancarlo Biagini \\ From Challanges in malaria research: Core science and innovation \\ Oxford, UK. 22-24 September 2014
}

It is hypothesised that intraerythrocytic malaria parasite metabolism is not just fulfilling the need for ATP generation, but is highly evolved to support rapid proliferation, similar to what is seen in other rapidly proliferating cells such as cancer cells. Evidence is presented that deregulated glycolytic activity coupled with impaired mitochondrial metabolism is a metabolic strategy to generate glycolytic intermediates essential for rapid biomass generation for schizogony.

The role of the parasite mitochondrion during key stages of the parasite life cycle makes it an attractive target for the development of novel prophylaxis, treatment and transmission blocking drugs. Using a targeted pharmacometabolomic approach, additional mitochondrial targets with therapeutic potential are identified and the potential of the development of inhibitors against these novel targets is discussed in the context of recent experiences with $b_{1}$ and dihydroorotate dehydrogenase-targeting drug development programmes and within the context of current target product profiles for the malaria elimination agenda.

Submit your next manuscript to BioMed Central and take full advantage of:

- Convenient online submission

- Thorough peer review

- No space constraints or color figure charges

- Immediate publication on acceptance

- Inclusion in PubMed, CAS, Scopus and Google Scholar

- Research which is freely available for redistribution

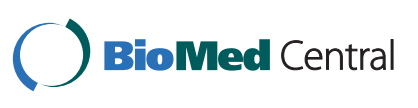

(c) 2014 Biagini; licensee BioMed Central Ltd. This is an Open Access article distributed under the terms of the Creative Commons Attribution License (http://creativecommons.org/licenses/by/4.0), which permits unrestricted use, distribution, and reproduction in any medium, provided the original work is properly cited. The Creative Commons Public Domain Dedication waiver (http:// creativecommons.org/publicdomain/zero/1.0/) applies to the data made available in this article, unless otherwise stated. 